ISSN: 1858-4837; E-ISSN: 2598-019X

Volume 15, Nomor 1 (2020),

https://jurnal.uns.ac.id/region

DOI: 10.20961/region.v15i1.26698

\title{
Tingkat keterkaitan fisik kota inti dan kota satelit di kawasan metropolitan PEKANSIKAWAN (Pekanbaru, Siak, Kampar, Pelalawan)
}

The physical linkages level between the core city and its satellite cities in the PEKANSIKAWAN (Pekanbaru, Siak, Kampar, Pelalawan) metropolitan area

\author{
T I Nurrady ${ }^{1}$, Dewanti ${ }^{1}$, dan Y Herwangi ${ }^{1}$ \\ ${ }^{1}$ Departemen Arsitektur dan Perencanaan, Fakultas Teknik Universitas Gadjah Mada
}

Corresponding author's email: teukuichsannurrady@gmail.com

\begin{abstract}
Abstrak. PEKANSIKAWAN merupakan konsep kawasan metropolitan yang mengintegrasikan tiga wilayah kabupaten di Provinsi Riau yang ditujukan agar sektor strategis daerah dapat dikembangkan. Dalam konsep ini terjadi interaksi wilayah antara wilayah kota inti (Pekanbaru) dan delapan kota satelit disekitarnya yang meliputi Minas, Kandis, Siak Sri Indrapura, Perawang, Bangkinang, Petapahan, Lipat Kain dan Pangkalan Kerinci. Salah satu isu strategis yang terdapat dalam pengembangan konsep ini adalah pelayanan insfrastruktur fisik (prasarana pendukung). Tujuan dari penelitian ini adalah menemukenali tingkat keterkaitan fisik kota inti dan kota satelit di kawasan metropolitan PEKANSIKAWAN. Metode skoring dan pembobotan digunakan untuk melihat tingkat keterkaitan fisik kota satelit dan kota inti yang dilakukan terhadap tujuh indikator yang telah ditentukan. Hasil dari analisis tersebut menunjukkan kota satelit Bangkinang, Pangkalan Kerinci dan Minas memiliki keterkaitan fisik yang cenderung lebih baik (dibandingkan dengan kota satelit lain) dengan kota inti Pekanbaru. Hal ini disebabkan karena ketiga kota satelit tersebut terhubung langsung dengan jaringan penghubung utama Sumatera yang menghubungkan Kota Pekanbaru sebagai ibukota Provinsi Riau dengan provinsiprovinsi lain di Sumatera. Selain itu, kuatnya keterkaitan fisik tersebut juga menjadikan Bangkinang, Pangkalan Kerinci, Minas, dan Kota Pekanbaru merupakan wilayah terintegrasi lebih baik dibandingkan wilayah lain di PEKANSIKAWAN.
\end{abstract}

Kata Kunci: Interaksi antar Wilayah; Keterkaitan Fisik; Kota Inti; Kota Satelit; Metropolitan

Received: January 09, 2019; Accepted: January 17, 2019; Available online: January 10, 2020

Copyright $@$ 2020, REGION: Jurnal Pembangunan Wilayah dan Perencanaan Partisipatif 


\begin{abstract}
PEKANSIKAWAN is a metropolitan area concept that integrate three regencies in Riau Province, so that regional strategic sectors can be developed. In this concept, there are interactions between regions which can be seen from the interaction of the core city (Pekanbaru City) and the eights surrounding satellite cities, i.e. Minas, Kandis, Siak Sri Indrapura, Perawang, Bangkinang, Petapahan, Lipat Kain and Pangkalan Kerinci. One of this concept's strategic issue is the physical infrastructure services (the supporting infrastructure). The aim of this research is to find the level of physical connection from the core city and its satellite cities in the PEKANSIKAWAN metropolitan area. Scoring and weighting methods are used to see the level of the physical linkages between the core city and its satellites based on seven physical linkage indicators that have been defined. The results show that the satellite cities of Bangkinang, Pangkalan Kerinci, and Minas have better physical linkages with the core city of Pekanbaru (compared to other satellite cities). This is due to the fact that the three satellite cities are connected directly to Sumatra's main connecting network that connects Pekanbaru City, as the capital of Riau Province, with other provinces in Sumatra. Furthermore, those physical linkages also make Bangkinang, Pangkalan Kerinci, Minas, and Pekanbaru City become a better integrated region than the other regions in PEKANSIKAWAN.
\end{abstract}

Keywords: Core City; Interactions between Regions; Metropolitan; Physical Linkages; Satellites City

\title{
1. Pendahuluan
}

PEKANSIKAWAN merupakan konsep kawasan metropolitan di Provinsi Riau yang bertujuan untuk mengembangkan sektor-sektor strategis daerah dengan menghubungkan Pekanbaru sebagai Kota Inti, dengan Minas, Kandis, Siak Sri Indrapura, Perawang, Bangkinang, Petapahan, Lipat Kain dan Pangkalan Kerinci sebagai kota satelit. Pengembangan Kawasan Metropolitan PEKANSIKAWAN tidak lepas dari beberapa isu strategis. Isu strategis yang dihadapi pengembangan PEKANSIKAWAN ini didominasi oleh isu ekonomi yang terkait dengan pelayanan infrastruktur fisik.

Menurut Katherina [1], pada dasarnya pertumbuhan wilayah tidak terjadi pada semua tempat, tetapi hanya pada wilayah-wilayah yang memiliki sektor strategis, yang sering disebut kutub atau pusat pertumbuhan. Perkembangan kota yang signifikan sering kali menurunkan daya tampung kota yang menyebabkan adanya kebutuhan lokasi atau pusat kegiatan baru. Dengan kata lain, tekanan pertambahan jumlah penduduk mengakibatkan semakin meningkatnya kebutuhan akan berbagai fasilitas dan sarana pelayanan kehidupan kota, sehingga untuk mengatasinya muncul sebuah konsep pengembangan kota yang berupa pengembangan kota-kota baru di sekitar kota besar yang telah sebelumnya ada. Kota baru, baik berupa kota baru satelit maupun kota baru mandiri, merupakan salah satu upaya pengembangan kota yang terencana [2].

Yudohusodo [2] menyatakan bahwa kota baru satelit merupakan permukiman skala besar yang dikembangkan sebagai tempat tinggal yang letaknya terpisah dari kota inti meskipun secara fungsional sangat tergantung dengan kota inti (domitory town). Ketergantungan antara kota satelit dan kota ini akan membentuk keterkaitan antar wilayah. Keterkaitan 
antar wilayah dapat memberi gambaran tentang hubungan antar wilayah dan sering diartikan sebagai interaksi yang secara harfiah dapat diartikan lagi sebagai 'hal yang saling mempengaruhi' [3]. Interaksi spasial ini dapat diidentifikasi sebagai ketergantungan antar wilayah secara geografis yang dilalamnya menjelaskan tentang aliran atau perpindahan barang (commodity flow), kemudian diterapkan pada gerak manusia dan gagasan (ideas), yang dari penjelasan terebut dapat dibentuk model gravitasi untuk komoditi, telepon, lalu lintas, migrasi dan beberapa hal lainnya [4].

Interaksi antar wilayah bertumpu pada ketersediaan jaringan prasarana pendukung. Dengan kata lain, ketersediaan jaringan prasarana (yang paling umum jaringan transportasi) sangat mempengaruhi seperti apa interaksi antar wilayah yang terjadi, atau dapat disebut sebagai leading sector [5]. Hal ini sejalan dengan pendapat Rodinelli [6] dan Bendavid-Val [7] yang menyatakan bahwa prasarana transportasi penghubung wilayah merupakan elemen keterkaitan fisik yang merupakan salah satu jenis keterkaitan spasial wilayah.

Berdasarkan latar belakang tersebut, maka muncul pertanyaan penelitian yang mendorong peneliti untuk mengaji tentang besar kecilnya interaksi antara kota inti dan kota satelit di PEKANSIKAWAN yang dilihat dari keterkaitan fisik, faktor apa yang mempengaruhinya, dan bagaimana keterkaitan fisik tersebut mempengaruhi interaksi antar kota inti dan kota satelit di kawasan metropolitan PEKANSIKAWAN. Secara garis besar, penelitian ini bertujuan untuk menemukenali tingkat keterkaitan fisik kota inti dan kota satelit di kawasan metropolitan PEKANSIKAWAN.

\section{Metodologi}

Metode penelitian yang digunakan dalam menjawab pertanyaan penelitian ini menggunakan metode deduktif kuantitatif. Tujuan dari penelitian ini adalah untuk mengetahui keterkaitan fisik antara kota inti dan kota satelit di kawasan metropolitan PEKANSIKAWAN. Proses analisis pada penelitian ini dapat dilihat pada gambar 1 berikut.

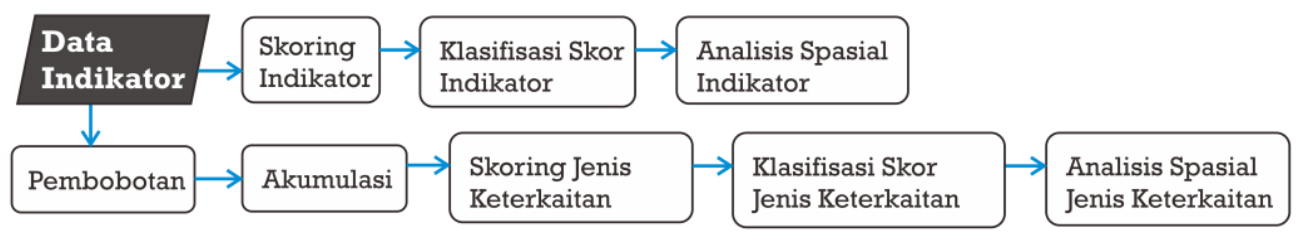

Gambar 1. Proses analisis penelitian

\subsection{Indikator penelitian}

Dalam penelitian ini, keterkaitan fisik dibatasi sebagai "close system", artinya keterkaitan yang diteliti hanya keterkaitan yang terjadi antara kota inti dan kota satelit yang berada dalam konsep pengembangan kawasan PEKANSIKAWAN. Keterkaitan fisik antar kota inti dan kota satelit menjadi "independent variable", dan hasil besar keterkaitan menjadi "dependent variable". 
Penjabaran detail mengenai kebutuhan data terkait penilaian indikator-indikator terhadap elemen-elemen analisis masing-masing variable dapat dilihat pada Tabel 1.

Tabel 1. Indikator penelitian [6-7].

\begin{tabular}{lll}
\hline Tipe & Elemen-elemen & Indikator \\
\hline & - Jaringan Jalan & Kualitas Jalan \\
& & Lama Tempuh \\
& & Aksesibilitas Jarak \\
Keterhubungan Fisik & Jaringan Transportasi Darat & Konektivitas \\
& & Jenis Angkutan \\
& & Jumlah Armada \\
& Frekuensi Keberangkatan \\
& Biaya Angkutan \\
\hline
\end{tabular}

\subsection{Skoring dan pembobotan}

Menurut Sholahudin [8], metode skoring dapat dikatakan sebagai suatu metode pemberian skor atau nilai terhadap masing-masing parameter sehingga dapat ditentukan tingkat kemampuan parameter tersebut. Pembobotan merupakan suatui metode yang biasa digunakan terhadap parameter yang memiliki karakter dan peranan yang berbeda [8].

Menurut Sihotang [9], model skoring atau yang biasa juga disebut weighted linier combination (WCL) sering digunakan untuk merepresentasikan tingkat kedekatan, keterkaitan atau beratnya efek tertentu pada fenomena spasial yang didapat melalui penjumlahan skor yang diberikan pada setiap parameter yang pada akhirnya menghasilkan klasifikasi tingkat keterkaitan parameter yang diamati.

Sihotang [10] menyatakan bahwa pengambil keputusan pasti akan memberikan besaran bobot kepentingan yang berbeda untuk setiap parameter. Pada penelitian ini, masing masing indikator dilakukan pemberian nilai terhadap masing-masing kota satelit. Nilai dari setiap kota satelit ditentukan dari besarnya data masing-masing kota satelit dan dapat dilihat pada persamaan berikut.

$$
X=\frac{\text { Data Indikator Kota } i}{\sum \text { Data Indikator }} \times \text { Skala Skor }
$$

Dimana $X$ merupakan besarnya skor masing-masing kota satelit pada setiap indikator, data indikator i adalah data indikator pada kota satelit i, dan skala skor adalah skala/rentang pemberian skor (dalam penelitian ini skala skor adalah 100). Dari persamaan tersebut dapat diketahui bahwa skor sebuah kota satelit bersifat relatif terhadap skor kota satelit lain, dan akumulasi seluruh skor kota satelit berjumlah 100.

Adapun persamaan untuk melihat seberapa besar keterkaitan parameter dalam sebuah analisa, sebagai berikut [10]: 


$$
S=\sum w i \times x i
$$

Dimana $S$ adalah tingkat keterkaitan, wi adalah bobot parameter $i$ dan $x i$ adalah skor parameter $i$. Disamping itu, menurut Drobe dan Lisec (2009, dalam Sihotang, [8]), hasil akhir dari sistem skoring adalah tingkat keterkaitan pada parameter keluaran, sehingga persamaan dalam menentukan rentang skor dapat dilihat sebagai berikut:

$$
\text { Rentang Skor }=\left(X_{\max }-X_{\min }\right) / m
$$

Dimana $X_{\max }$ adalah skor tertinggi, $X_{\min }$ adalah skor terendah dan $m$ adalah jumlah rentang yang diinginkan dalam analisa. Proses analisis penelitian dapat dilihat pada gambar berikut.

\subsection{Pembobotan indikator}

Menurut Adisasmita [2], aspek transportasi memiliki peran sebagai leading sector dalam pengembangan wilayah. Oleh karena itu hal yang paling fundamental dalam aspek transportasi adalah prasarana jalan. Adisasmita [2] juga menyebutkan hal tersebut harus lebih dulu ada sebelum memenuhi kebutuhan transportasi.

Ada 8 karakteristik jasa transportasi [2], yaitu; (1) lancar/cepat; (2) selamat/aman; (3) berkapasitas; (4) tertib/teratur; (5) komprehensif; (6) bertanggungjawab; (7) murah; dan (8) nyaman. Selain itu, menurut Munawar [11], faktor utama yang mempengaruhi dalam menentukan seberapa besar jumlah armada angkut meliputi faktor muat (load factor) dan kapasitas kendaraan.

Berdasarkan itu, dalam penelitian ini indikator kondisi jalan memiliki bobot 2 karena merupakan prasarana yang paling mendasar dan mempengaruhi indikator lain. Sedangkan indikator jumlah armada angkut dipengaruhi faktor eksternal (diluar indikator yang telah ditentukan) dan dinilai lebih independen. Konektivitas, aksesibilitas, dan durasi perjalanan memiliki bobot 1,5 karena dinilai mempengaruhi biaya angkut dan frekuensi keberangkatan. Sedangkan biaya angkut dan frekuensi keberangkatan memiliki bobot 1 dan 0,5 karena dinilai dipengaruhi oleh banyak faktor lain seperti kondisi jalan, konektivitas, aksesibilitas jarak, dan durasi perjalanan. Informasi detail terkait pembobotan indikator dapar dilihat pada Tabel 2. 
Tabel 2. Pembobotan indikator

\begin{tabular}{|c|c|c|c|}
\hline No. & $\begin{array}{l}\text { Indikator } \\
\text { Parameter }\end{array}$ & $\begin{array}{c}\text { Bobot } \\
\text { Penilaian }\end{array}$ & Keterangan \\
\hline 1 & Kondisi Jalan & 2 & $\begin{array}{l}\text { Memiliki peran utama dalam elemen jaringan jalan karena } \\
\text { merupakan prasarana penghubung utama antara kota inti } \\
\text { dan kota satelit. (Leading Sector) }\end{array}$ \\
\hline 2 & Konektivitas & 1,5 & $\begin{array}{l}\text { Penting karena berpengaruh kepada ada atau tidaknya } \\
\text { keterhubungan kota inti dan kota satelit secara langsung, } \\
\text { namun memiliki ketergantungan pada keberadaan jaringan } \\
\text { dan kondisi. }\end{array}$ \\
\hline 3 & $\begin{array}{l}\text { Aksesibilitas } \\
\text { Jarak }\end{array}$ & 1,5 & $\begin{array}{l}\text { Penting karena berpengaruh kepada menentukan kota } \\
\text { satelit mana yang paling mudah/sulit diakses dari kota inti, } \\
\text { namun memiliki ketergantungan pada keberadaan jaringan } \\
\text { dan kondisi. }\end{array}$ \\
\hline 4 & $\begin{array}{l}\text { Durasi } \\
\text { Perjalanan }\end{array}$ & 1,5 & $\begin{array}{l}\text { Penting karena berpengaruh pada pemilihan perjalanan } \\
\text { commuter pekerja metropolitan, namun memiliki } \\
\text { ketergantungan pada keberadaan jaringan dan kondisi. }\end{array}$ \\
\hline 5 & $\begin{array}{l}\text { Jumlah Armada } \\
\text { Angkut }\end{array}$ & 2 & $\begin{array}{l}\text { Memiliki peran utama dalam elemen jaringan transportasi } \\
\text { karena berperan sebagai sarana umum yang } \\
\text { mengakomodir mobilitas penduduk antara kota inti dan } \\
\text { kota satelit. }\end{array}$ \\
\hline 6 & $\begin{array}{l}\text { Frekuensi } \\
\text { Keberangkatan }\end{array}$ & 0,5 & $\begin{array}{l}\text { Tidak terlalu mempengaruhi kepada keterkaitan Fisik, } \\
\text { namun merupakan salah satu indikator pada jaringan } \\
\text { transportasi }\end{array}$ \\
\hline 7 & Biaya Angkut & 1 & Hanya mempengaruhi pada pemilihan alternatif angkutan \\
\hline & Total & 10 & \\
\hline
\end{tabular}

\section{Hasil dan pembahasan}

\subsection{Analisis skoring dan spasial indikator}

3.1.1 Kualitas Jalan. Kondisi jaringan jalan di kawasan metropolitan PEKANSIKAWAN mayoritas memiliki kondisi baik. Kondisi jalan terbaik terdapat pada jaringan jalan akses Kota Pekanbaru menuju Minas dan Pangkalan Kerinci (99,43\% dan 98,60\%). Sedangkan kondisi jalan paling buruk terdapat pada akses jalan Kota Pekanbaru menuju Petapahan (59,25\%). 
Tabel 3. Skoring indikator kondisi jalan.

\begin{tabular}{|c|c|c|c|c|c|c|c|c|c|}
\hline \multirow{3}{*}{ No. } & & \multicolumn{4}{|c|}{ Data Kondisi Jalan } & \multirow{3}{*}{$\begin{array}{c}\text { Panjang } \\
\text { Jalan } \\
(\mathrm{km})\end{array}$} & \multirow{3}{*}{$\begin{array}{l}\text { Total } \\
\text { Data } x \\
\text { Bobot }\end{array}$} & \multirow{3}{*}{$\begin{array}{c}\text { Kinerja } \\
\text { Jalan } \\
\%\end{array}$} & \multirow{3}{*}{$\begin{array}{c}\text { Skor } \\
\text { Kondisi } \\
\text { Jalan } \\
\text { Skala } \\
100\end{array}$} \\
\hline & $\begin{array}{l}\text { Jaringan Jalan } \\
\text { dari Pekanbaru }\end{array}$ & $\begin{array}{l}\text { Baik } \\
(\mathrm{km})\end{array}$ & $\begin{array}{c}\text { Sedang } \\
(\mathrm{km})\end{array}$ & $\begin{array}{c}\text { Rusak } \\
\text { ringan } \\
(\mathrm{km}) \\
\end{array}$ & $\begin{array}{c}\text { Rusak } \\
\text { Berat } \\
(\mathrm{km})\end{array}$ & & & & \\
\hline & Bobot Data & 1 & 0,75 & 0,5 & 0,25 & & & & \\
\hline & Minas & 35,15 & 0,20 & 0,00 & 0,00 & 35,35 & & & \\
\hline 1 & data $\times$ bobot & 35,15 & 0,15 & 0,00 & 0,00 & & 35,30 & 6 & 13,15 \\
\hline & Kandis & 73,37 & 1,60 & 0,10 & 0,10 & 75,17 & & & \\
\hline 2 & data $\times$ bobot & 73,37 & 1,20 & 0,05 & 0,03 & & 74,65 & 99,30 & 13,07 \\
\hline & Siak & 98,27 & 24,53 & 1,00 & 0,30 & 124,10 & & & \\
\hline 3 & dato & & & & & & 117,2 & 94,47 & 12,44 \\
\hline & adto & 98,27 & 18,40 & 0,50 & 0,08 & & 4 & & \\
\hline 4 & Perawang & 56,40 & 1,70 & 2,10 & 0,20 & 60,40 & & & \\
\hline 4 & data $\times$ bobot & 56,40 & 1,28 & 1,05 & 0,05 & & 58,78 & 1 & 12,81 \\
\hline & Bangkinang & 79,46 & 0,90 & 1,80 & 0,00 & 82,16 & & & \\
\hline 5 & data $\times$ bobot & 79,46 & 0,67 & 0,90 & 0,00 & & 81,04 & 3 & 2,99 \\
\hline 6 & Petapahan & 36,01 & 0,10 & 9,30 & 15,37 & 60,78 & & & \\
\hline 6 & data $\times$ bobot & 36,01 & 0,08 & 4,65 & 3,84 & & 44,58 & & 9,66 \\
\hline & Lipat Kain & 58,44 & 4,60 & 1,62 & 0,00 & 64,66 & & & \\
\hline 7 & $\begin{array}{l}\text { data } \times \text { bobot } \\
\text { Pangkalan }\end{array}$ & 58,44 & 3,45 & 0,81 & 0,00 & & 62,70 & 7 & 12,77 \\
\hline 8 & Kerinci & 63,63 & 0,90 & 0,00 & 0,00 & 64,53 & & 99,65 & 13,12 \\
\hline & data $\times$ bobot & 63,63 & 0,68 & 0,00 & 0,00 & & 64,30 & & \\
\hline & & & & & & & Total & 759,54 & 100,00 \\
\hline
\end{tabular}

Dari Tabel 3 dapat diketahui bahwa jalan dengan kualitas paling baik adalah jalan yang menghubungkan Kota Pekanbaru dan Minas (13,15 point) disusul Pangkalan Kerinci $(13,12$ point), minas dan Bangkinang. Sedangkan kualitas jalan paling buruk adalah jalan yang menghubungkan Kota Pekanbaru dan Petapahan dengan skor 9,66 point. 


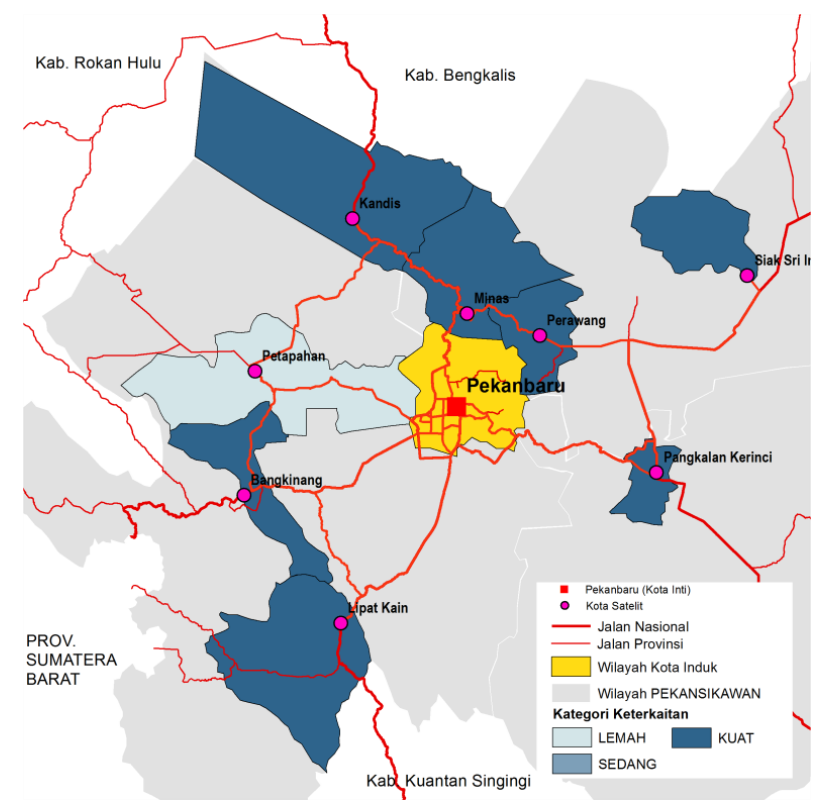

Gambar 2. Klasifikasi hasil skoring kualitas jalan di PEKANSIKAWAN

Secara spasial terlihat bahwa hampir seluruh kota satelit memiliki kondisi jalan yang baik sebagai penghubung dengan kota inti (Pekanbaru), kecuali kota satelit Petapahan. Hal tersebut disebabkan jalan-jalan penghubung kota inti Pekanbaru dan kota-kota satelit merupakan jalan dengan fungsi utama menghubungkan Kota Pekanbaru dengan provinsiprovinsi tetangga seperti Riau - Sumatera Utara (Minas dan Kandis), Riau - Sumatera Barat (Bangkinang) dan Riau - Jambi (Pangkalan Kerinci).

3.1.2 Konektivitas. Untuk mengukur keterhubungan (connectivity) suatu daerah dengan daerah lainnya dapat menggunakan jumlah jaringan jalan yang langsung menghubungkan kedua daerah tersebut. Hal tersebut juga dijelaskan oleh Rodrigue, J. P., et al [12], yang menyatakan bahwa pada dasarnya konektifitas dapat dilihat sebagai jaringan penghubung antar lokasi (node) tanpa mempertimbangkan jarak.

Tabel 4. Skoring indikator konektivitas.

\begin{tabular}{llcc}
\hline No. & $\begin{array}{c}\text { Konektivitas Kota Inti } \\
\text { dan Kota Satelit }\end{array}$ & $\begin{array}{c}\text { Jumlah } \\
\text { Konektivitas }\end{array}$ & $\begin{array}{c}\text { Skor } \\
\text { Konektivitas }\end{array}$ \\
\cline { 4 - 4 } & Minas & 1 & Skala 100 \\
\hline 1 & Kandis & 0 & 11,11 \\
2 & Siak Sri Indrapura & 0 & 0,00 \\
3 & 0 & 0,00 \\
4 & Perawang & 3 & 0,00 \\
5 & Bangkinang & 1 & 33,33 \\
6 & Petapahan & 2 & 11,11 \\
7 & Lipat Kain & 2 & 22,22 \\
8 & Pangkalan Kerinci & 9 & 22,22 \\
& Total Konektivitas & 9 & 100 \\
\hline
\end{tabular}




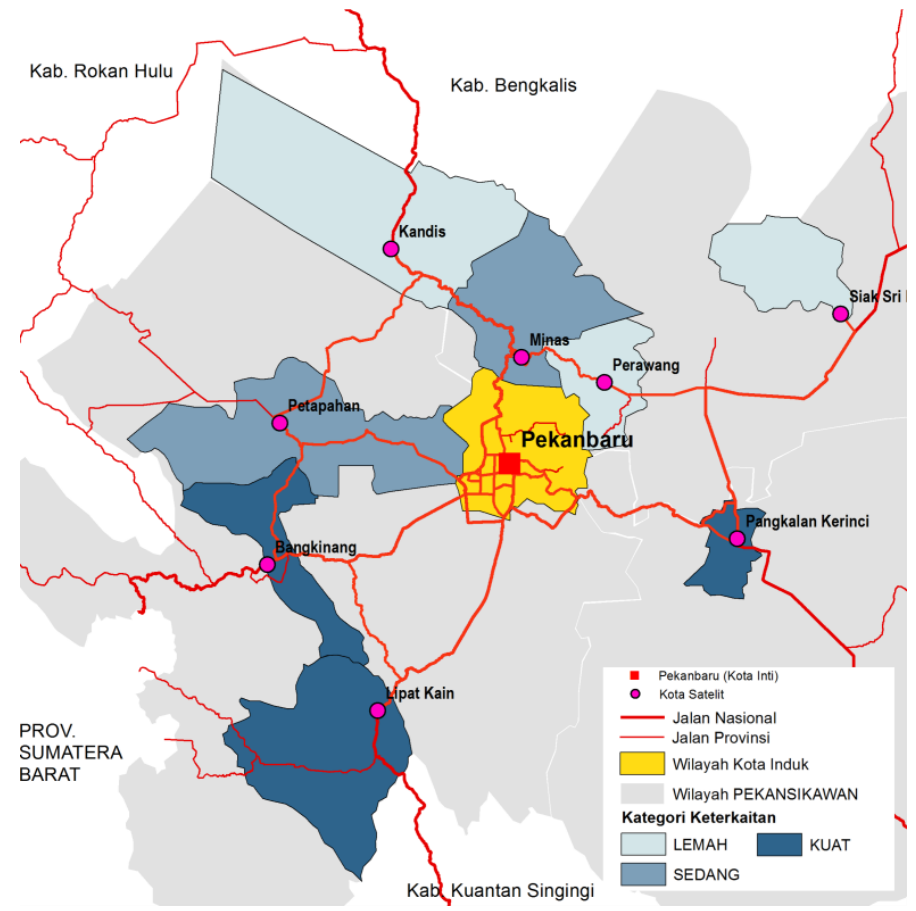

Gambar 3. Klasifikasi hasil skoring konektivitas di PEKANSIKAWAN

Dari tabel 4 dapat diketahui bahwa kota satelit yang memliki skor konektivitas terbesar adalah Bangkinang (33,3 point), disusul Lipat Kain dan Pangkalan Kerinci (22,2 point). Sedangkan kota satelit yang tidak memiliki keterhubungan langsung (seperti Kandis, Siak Sri Indrapura, dan Perawang) tidak memiliki skor keterhubungan/konektivitas.

Secara spasial terlihat bahwa Pangkalan Kerinci, Lipat Kain dan Bangkinang merupakan kota satelit yang memiliki keterhubungan langsung lebih dari satu pilihan jalur dengan kota inti (Pekanbaru), sehingga penduduk yang melakukan perjalanan dari Pekanbaru menuju kotakota satelit tersebut memiliki beberapa pilihan jalur untuk melakukan perjalanan, demikian sebaliknya. Selain itu adanya beberapa alternatif jalur antara kota inti dan kota satelit membuat keterhubungan antara keduanya semakin kuat, baik dilihat dari sisi kapasitas lalulintas/daya dukung lalulintas ataupun sebagai alternatif jika salah satu jalur terputus.

3.1.3 Aksesibilitas jarak. Aksesibilitas jarak merupakan salah satu ukuran seberapa mudah suatu lokasi/daerah dapat diakses/dijangkau. Dalam penelitian ini aksesibilitas dilihat dari jarak antara kedua kota (kota inti dan kota satelit), hal tersebut sejalan dengan pernyataan Bhat et al [13] yang menjelaskan bahwa ukuran aksesibilitas yang dinilai paling sederhana adalah jarak dan dapat menjadi sebuah ukuran pemisahan. 
Tabel 5. Skoring indikator aksesibilitas jarak

\begin{tabular}{|c|c|c|c|c|}
\hline No. & $\begin{array}{c}\text { Aksesibilitas Kota Inti } \\
\text { dan Kota Satelit }\end{array}$ & $\begin{array}{c}\text { Jarak } \\
\text { Terdekat } \\
(\mathrm{km})\end{array}$ & $\begin{array}{c}\text { Kinerja } \\
\text { Aksesibilitas Jarak } \\
\text { Angka Konversi- } \\
\text { Jarak Terdekat }\end{array}$ & $\begin{array}{c}\text { Skor } \\
\text { Aksesibilitas } \\
\text { (Skala 100) }\end{array}$ \\
\hline 1 & Minas & 35,35 & 124,1 & 17,5 \\
\hline 2 & Kandis & 75,17 & 84,3 & 11,9 \\
\hline 3 & Siak Sri Indrapura & 124,10 & 35,3 & 5,0 \\
\hline 4 & Perawang & 60,40 & 99,1 & 14,0 \\
\hline 5 & Bangkinang & 82,16 & 77,3 & 10,9 \\
\hline 6 & Petapahan & 60,78 & 98,7 & 13,9 \\
\hline 7 & Lipat Kain & 64,66 & 94,8 & 13,4 \\
\hline \multirow[t]{5}{*}{8} & Pangkalan Kerinci & 64,53 & 94,9 & 13,4 \\
\hline & Total & & 708,4 & 100,0 \\
\hline & Max & 124,10 & & \\
\hline & Min & 35,35 & & \\
\hline & $\begin{array}{r}\text { Angka Konversi } \\
(\text { max }+\min )\end{array}$ & 159,45 & & \\
\hline
\end{tabular}

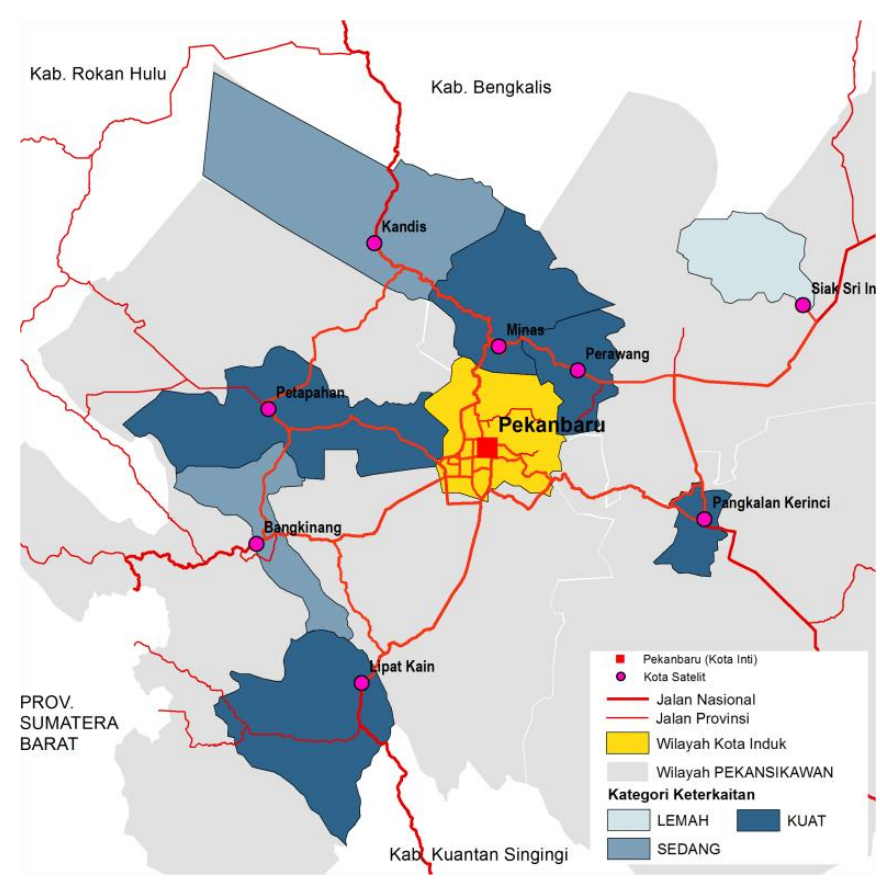

Gambar 4. Klasifikasi hasil skoring Aksesibilits jarak di PEKANSIKAWAN

Dari tabel 5 dapat diketahui bahwa kota satelit yang paling mudah diakses adalah Minas dengan skor 17,5 point, sedangkan kota satelit yang paling sulit diakses adalah Siak Sri Indrapura dengan skor 5,0 point.

Dari gambar 4 terlihat bahwa kota satelit Minas, Perawang, Petapahan, Lipat Kain, dan Pangkalan Kerinci merupakan kota yang paling mudah diakses dari kota inti Pekanbaru karena memiliki jarak yang paling dekat/pendek. Secara spasial, kota-kota satelit yang 
memiliki skor aksesibilitas yang sedang hingga besar dipengaruhi oleh jaraknya yang dekat dengan kota inti Pekanbaru. Selain itu wilayah Minas, Perawang, dan Petapahan juga berbatasan langung dengan wilayah Kota Pekanbaru.

3.1.4 Durasi perjalanan. Salah satu faktor yang menentukan mudahnya suatu akses suatu tempat adalah durasi perjalanan/lama tempuh. Dalam penelitian ini, durasi perjalanan yang akan lihat adalah durasi perjalanan antara kota inti (Kota Pekanbaru) dan delapan kota satelit yang ada dalam kawasan metropilitan PEKANSIKAWAN yang diukur dengan menggunakan mobil (kendaraan roda 4) pribadi dan dengan kecepatan berkisar antara 50 $\mathrm{km} / \mathrm{jam}$ hingga $60 \mathrm{~km} / \mathrm{jam}$.

Tabel 6. Skoring indikator durasi perjalanan.

\begin{tabular}{|c|c|c|c|c|}
\hline No. & $\begin{array}{l}\text { Durasi Perjalanan Kota } \\
\text { Inti dan Kota Satelit }\end{array}$ & $\begin{array}{l}\text { Rata-rata } \\
\text { Durasi } \\
\text { perjalanan } \\
\text { (menit) }\end{array}$ & $\begin{array}{l}\text { Kinerja Durasi } \\
\text { Perjalanan } \\
\text { Angka Konversi- } \\
\text { rata-rata durasi } \\
\text { perjalanan }\end{array}$ & $\begin{array}{l}\text { Skor Durasi Perjalanan } \\
\text { (Skala 100) }\end{array}$ \\
\hline 1 & Minas & 90,5 & 137,5 & 14,7 \\
\hline 2 & Kandis & 137,5 & 90,5 & 9,7 \\
\hline 3 & Siak Sri Indrapura & 121,5 & 106,5 & 11,4 \\
\hline 4 & Perawang & 116,0 & 112,0 & 12,0 \\
\hline 5 & Bangkinang & 93,5 & 134,5 & 14,4 \\
\hline 6 & Petapahan & 92,0 & 136,0 & 14,5 \\
\hline 7 & Lipat Kain & 119,0 & 109,0 & 11,6 \\
\hline \multirow[t]{5}{*}{8} & Pangkalan Kerinci & 118,0 & 110,0 & 11,8 \\
\hline & Total & & 936,0 & 100,0 \\
\hline & Max & 137,5 & & \\
\hline & Min & 90,5 & & \\
\hline & $\begin{array}{r}\text { Angka Konversi } \\
\text { (max+min) }\end{array}$ & 228,0 & & \\
\hline
\end{tabular}

Dari tabel 6 dapat dilihat bahwa point tertinggi terletak pada lama tempuh antara Kota Pekanbaru dan Minas (14,7 point), dan skor yang tidak terlalu jauh juga terletak pada lama tempuh antara Kota Pekanbaru dan Bangkinang dan Petapahan (14,4 point dan 14,5 point). 


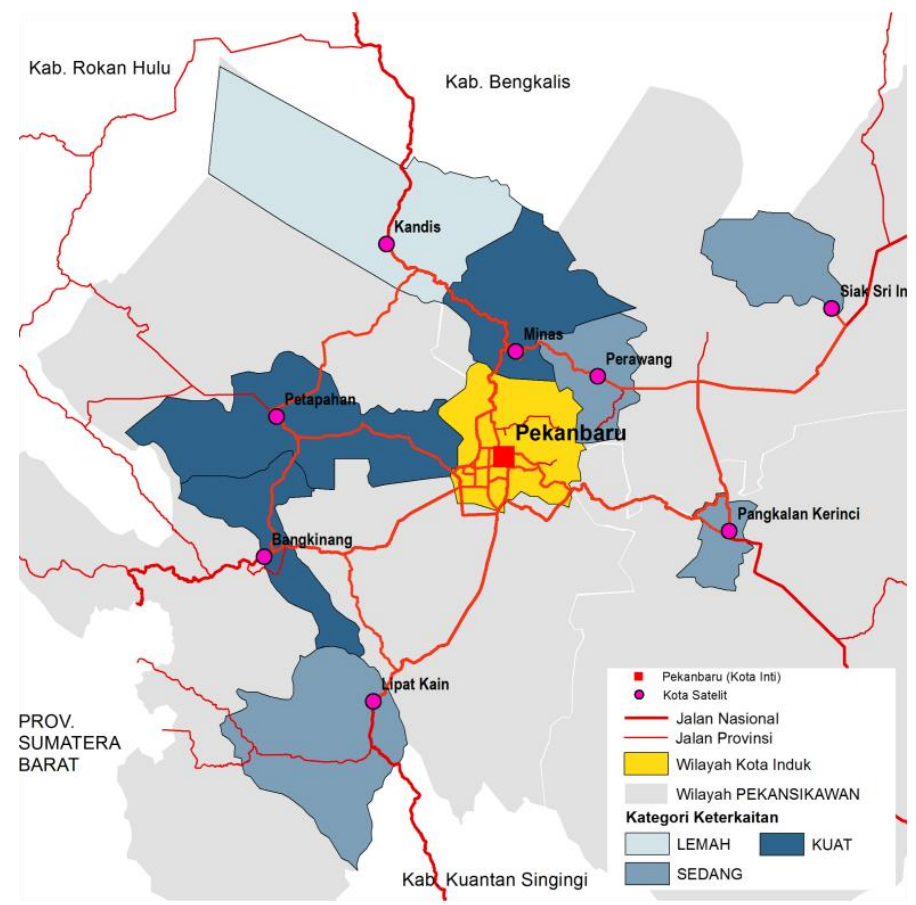

Gambar 5. Klasifikasi hasil skoring durasi perjalanan di PEKANSIKAWAN

Dari gambar 5 dapat dilihat kota satelit yang memiliki waktu tempuh atau durasi perjalanan sedang hingga kecil (kategori kuat) adalah kota-kota satelit yang memiliki keterhubungan langsung dengan kota inti Pekanbaru (kecuali Perawang), berbatasan langsung dan memiliki jarak yang tergolong dekat dengan Pekanbaru. Dari seluruh faktor penyebab tersebut, faktor jarak dan konektivitas adalah faktor yang sangat mempengaruhi lama tempuh atau durasi perjalanan antara kota inti dan kota satelit.

3.1.5 Jumlah armada angkut. Analisa jumlah armada angkut didapat dari penjumlahan armada angkut AKDP dan AJDP antara kota inti dan kota satelit sebanyak 869 unit (terdaftar) dan 1.178 unit (transit). Mengingat terdapat perbedaan kualitas antara angkutan dengan tujuan asli (terdaftar) dan tujuan kota lain namun melewati kota satelit (transit), maka perlu dilakukan pembobotan terhadap angkutan dengan sifat tujuan berbeda.

Dari hasil analisa (tabel 7) didapat bahwa jumlah armada angkut terbesar terdapat pada trayek Kota Pekanbaru dan Bangkinang (22,6 point) dan Pangkalan Kerinci (19,7 point). Sedangkan skor terkecil terletak pada trayek Lipat kain (2,7 point) dan Perawang (5,9 point). 
Tabel 7. Skoring Indikator jumlah armada angkut

\begin{tabular}{|c|c|c|c|c|c|}
\hline \multirow{2}{*}{ No. } & \multirow{2}{*}{$\begin{array}{l}\text { Tujuan Angkutan } \\
\text { Antara Pekanbaru dan }\end{array}$} & \multicolumn{2}{|c|}{$\begin{array}{c}\text { Jumlah Armada } \\
\text { Angkut }\end{array}$} & \multirow{2}{*}{$\begin{array}{l}\text { Kinerja } \\
\text { Jumlah } \\
\text { Armada }\end{array}$} & \multirow{2}{*}{$\begin{array}{c}\text { Skor } \\
\text { Jumlah } \\
\text { Armada } \\
\text { Angkut }\end{array}$} \\
\hline & & Terdaftar & Transit & & \\
\hline & Bobot & 1 & 0,5 & & \\
\hline \multirow[t]{2}{*}{1} & Minas & 31 & 355 & \multirow{2}{*}{209} & \multirow{2}{*}{14,30} \\
\hline & data $\times$ bobot & 31 & 178 & & \\
\hline \multirow[t]{2}{*}{2} & Kandis & 0 & 347 & \multirow{2}{*}{174} & \multirow{2}{*}{11,90} \\
\hline & data $\times$ bobot & 0 & 174 & & \\
\hline \multirow[t]{2}{*}{3} & Siak Sri Indrapura & 185 & 10 & \multirow{2}{*}{190} & \multirow{2}{*}{13,03} \\
\hline & data $\times$ bobot & 185 & 5 & & \\
\hline \multirow[t]{2}{*}{4} & Perawang & 76 & 19 & \multirow{2}{*}{86} & \multirow{2}{*}{5,86} \\
\hline & data $\times$ bobot & 76 & 10 & & \\
\hline \multirow[t]{2}{*}{5} & Bangkinang & 329 & 0 & \multirow{2}{*}{329} & \multirow{2}{*}{22,57} \\
\hline & data $\times$ bobot & 329 & 0 & & \\
\hline \multirow[t]{2}{*}{6} & Petapahan & 5 & 280 & \multirow{2}{*}{145} & \multirow{2}{*}{9,95} \\
\hline & data $\times$ bobot & 5 & 140 & & \\
\hline \multirow[t]{2}{*}{7} & Lipat Kain & 10 & 60 & \multirow{2}{*}{40} & \multirow{2}{*}{2,74} \\
\hline & data $\times$ bobot & 10 & 30 & & \\
\hline \multirow[t]{3}{*}{8} & Pangkalan Kerinci & 233 & 107 & \multirow{2}{*}{287} & \multirow{2}{*}{19,65} \\
\hline & data $\times$ bobot & 233 & 54 & & \\
\hline & Total & 1505 & 1714 & 1458 & 100 \\
\hline
\end{tabular}

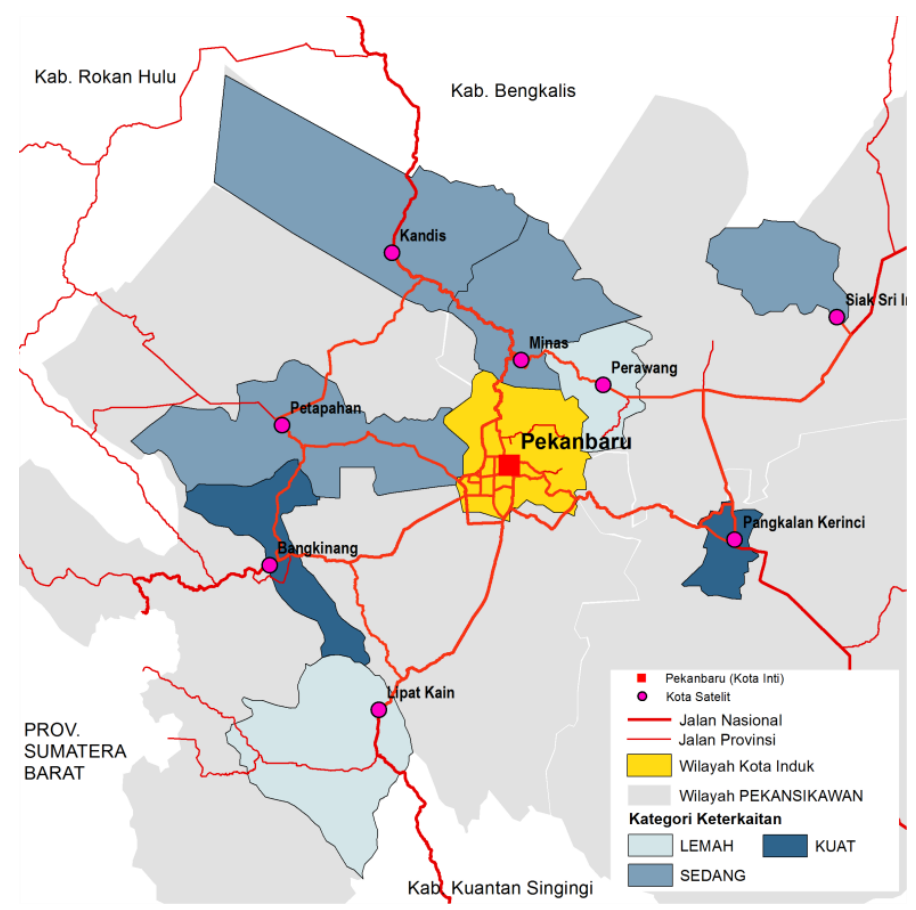

Gambar 6. Klasifikasi hasil skoring jumlah armada angkut di PEKANSIKAWAN 
Gambar 6 menunjukkan bahwa jumlah armada angkut terbanyak adalah armada angkut yang menghubungkan kota inti Pekanbaru dengan Bangkinang dan Pangkalan Kerinci. Sedangkan armada angkut dengan jumlah sedang adalah angkutan yang menghubungkan kota inti Pekanbaru dan kota satelit Kandis, Minas, Petapahan, dan Siak Sri Indrapura. Disisi lain meskipun Perawang memiliki kedekatan jarak dan berbatasan langsung dengan Pekanbaru, angkutan yang menghubungkan Perawang dan Pekanbaru tergolong kecil.

Dari analisa tersebut, terlihat bahwa jumlah angkutan terbanyak adalah angkutan yang menghubungkan Pekanbaru dengan kota satelit yang merupakan ibukota kabupaten (Pangkalan Kerinci Ibukota Kab. Pelelawan dan Bangkinang Ibukota Kab. Kampar) dan juga merupakan pusat kegiatan wilayah (PKW) Prov. Riau.

3.1.6 Frekuensi keberangkatan. Jumlah frekuensi keberangkatan AKDP dan AJDP sangat dipengaruhi oleh lama perjalanan atau waktu yang diperlukan kendaraan dari Pekanbaru menuju kota/daerah yang menjadi tujuan utama. Dari tabel 8 terlihat bahwa skor frekuensi keberangkatan terkecil terletak pada trayek Kota Pekanbaru - Bangkinang dengan skor 9,3 point. Hal tersebut dikarekan tidak ada trayek angkutan AJDP yang melayani rute Kota Pekanbaru - Bangkinang, sehingga rata-rata frekuensi keberangkatan hanya 5 kali per hari.

Tabel 8. Skoring indikator frekuensi keberangkatan.

\begin{tabular}{llcccr}
\hline & \multirow{2}{*}{$\begin{array}{c}\text { Frekuensi } \\
\text { Keberangkatan }\end{array}$} & \multicolumn{2}{c}{ Skor } \\
\cline { 3 - 6 } No. & \begin{tabular}{c} 
Kota Satelit \\
\cline { 3 - 5 }
\end{tabular} & $\begin{array}{c}\text { AKDP } \\
\text { (per hari) }\end{array}$ & $\begin{array}{c}\text { AJDP } \\
\text { (per hari) }\end{array}$ & $\begin{array}{c}\text { Jumlah } \\
\text { (per hari) }\end{array}$ & $\begin{array}{c}\text { Frekuensi } \\
\text { Keberangkatan }\end{array}$ \\
\hline 1 & Minas & 5 & 2 & 7 & 13,0 \\
2 & Kandis & 5 & 2 & 7 & 13,0 \\
3 & Siak Sri Indrapura & 5 & 2 & 7 & 13,0 \\
4 & Perawang & 5 & 2 & 7 & 13,0 \\
5 & Bangkinang & 5 & 0 & 5 & 9,3 \\
6 & Petapahan & 5 & 2 & 7 & 13,0 \\
7 & Lipat Kain & 5 & 2 & 7 & 13,0 \\
8 & Pangkalan Kerinci & 5 & 2 & 7 & 13,0 \\
& Total & & & 54 & 100,0 \\
\hline
\end{tabular}

Dari gambar 7 dapat diketahui bahwa Bangkinang merupakan satu-satunya kota dengan frekuensi keberangkatan paling sedikit/jarang (5 kali/hari) yang disebabkan angkutan yang menghubungkan kota inti Pekanbaru dan kota satelit Bangkinang hanya berupa AKDP tanpa adanya angkutan AJDP yang menghubungkan kedua wilayah tersebut. 


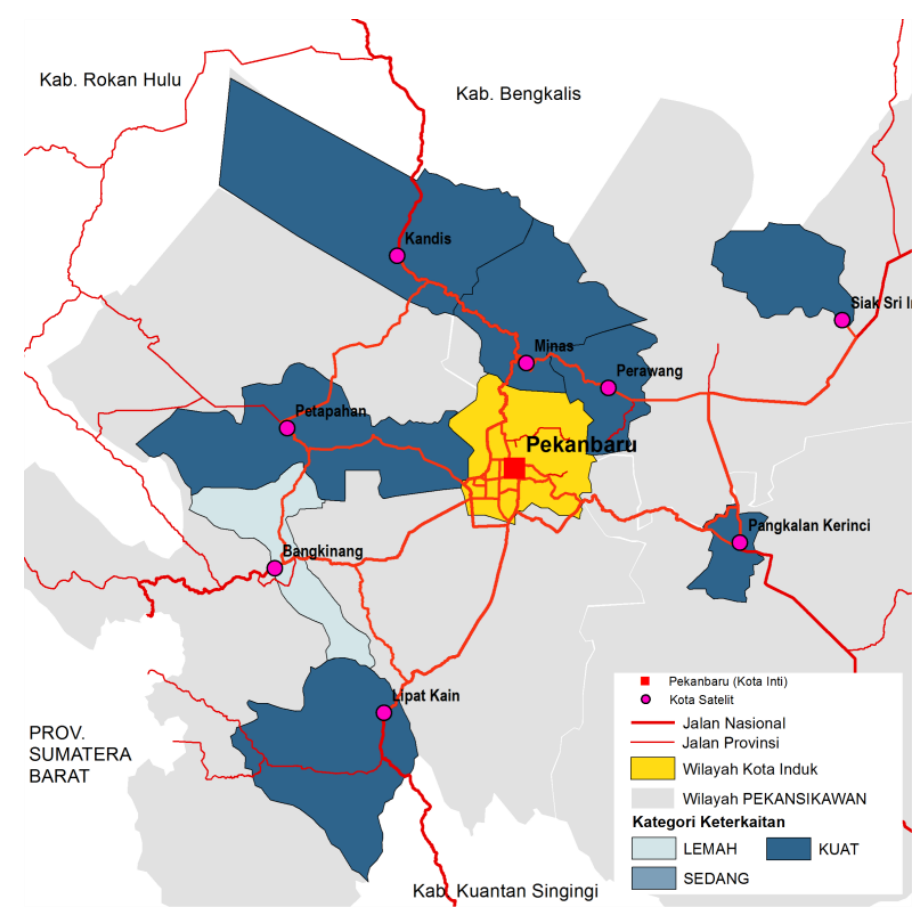

Gambar 7. Klasifikasi hasil skoring frekuensi keberangkatan di PEKANSIKAWAN

3.1.7 Biaya angkutan. Pada analisa biaya angkutan antara kota inti dan kota satelit di kawasan PEKANSIKAWAN terlihat bahwa tarif angkutan terkecil terletak pada trayek Pekanbaru-Bangkinang dengan rata-rata biaya angkutan sebesar $\mathrm{Rp} 40.000,-$. Hal ini disebabkan pada angkutan pada trayek ini hanya dilayani oleh angkutan AKDP yang lebih murah daripada AJDP. Oleh karena itu, hasil analisa skor biaya angkutan pada tabel 9 menunjukkan bahwa skor tertinggi terletak pada trayek Pekanbaru-Bangkinang dengan skor 20,7 point, sedangkan skor terendah perletak pada trayek Pekanbaru-Lipat Kain dengan skor 7,9 point.

Secara spasial, dapat diketahui besarnya biaya angkutan yang menghubungkan kota-kota satelit dengan kota inti Pekanbaru dipengaruhi oleh faktor spasial seperti jarak antara kedua wilayah seperti yang terlihat pada kota satelit Bangkinang, Kandis, Minas, dan Perawang. Namun pada kota satelit Siak Sri Indrapura, Pangkalan Kerinci, Petapahan dan Lipat Kain, biaya angkutan juga dipengaruhi oleh faktor jenis angkutan (AKDP dan AJDP). Seperti yang telah dijelaskan sebelumnya bahwa angkutan AJDP pada dasarnya memiliki tujuan yang lebih jauh sehingga biaya angkut menjadi mahal, namun pemberhentian pada kota satelit sebagai lokasi tujuan transit tidak menyebabkan biaya angkutan menjadi lebih murah (mengikuti tarif/biaya tujuan yang sebenarnya). 
Tabel 9. Skoring Indikator biaya angkutan

\begin{tabular}{|c|c|c|c|c|c|c|}
\hline \multirow{3}{*}{ No. } & \multirow{3}{*}{$\begin{array}{c}\text { Tujuan Angkutan } \\
\text { dari Pekanbaru }\end{array}$} & \multicolumn{3}{|c|}{ Tarif Angkutan } & \multirow{3}{*}{$\begin{array}{c}\text { Angka } \\
\text { Konversi - } \\
\text { Rata-rata }\end{array}$} & \multirow{3}{*}{$\begin{array}{l}\text { Skor Tarif } \\
\text { Angkutan }\end{array}$} \\
\hline & & AKDP & AJDP & Rata-rata & & \\
\hline & & Rata-rata (Rp) & Rata-rata (RP) & (Rp) & & \\
\hline 1 & Minas & 30.000 & 120.000 & 75.000 & 70.000 & 13,8 \\
\hline 2 & Kandis & 25.000 & 120.000 & 72.500 & 72.500 & 14,3 \\
\hline 3 & Siak Sri Indrapura & 100.000 & 100.000 & 100.000 & 45.000 & 8,9 \\
\hline 4 & Perawang & 30.000 & 100.000 & 65.000 & 80.000 & 15,8 \\
\hline 5 & Bangkinang & 40.000 & Tidak Ada & 40.000 & 105.000 & 20,7 \\
\hline 6 & Petapahan & 50.000 & 140.000 & 95.000 & 50.000 & 9,9 \\
\hline 7 & Lipat Kain & 50.000 & 160.000 & 105.000 & 40.000 & 7,9 \\
\hline \multirow[t]{6}{*}{8} & Pangkalan Kerinci & 40.000 & 160.000 & 100.000 & 45.000 & 8,9 \\
\hline & Total & & & & 507.500 & 100,0 \\
\hline & & & Max & 105.000 & & \\
\hline & & & Min & 40.000 & & \\
\hline & & & Angka Konversi & & & \\
\hline & & & $(\max +\min )$ & 145.000 & & \\
\hline
\end{tabular}

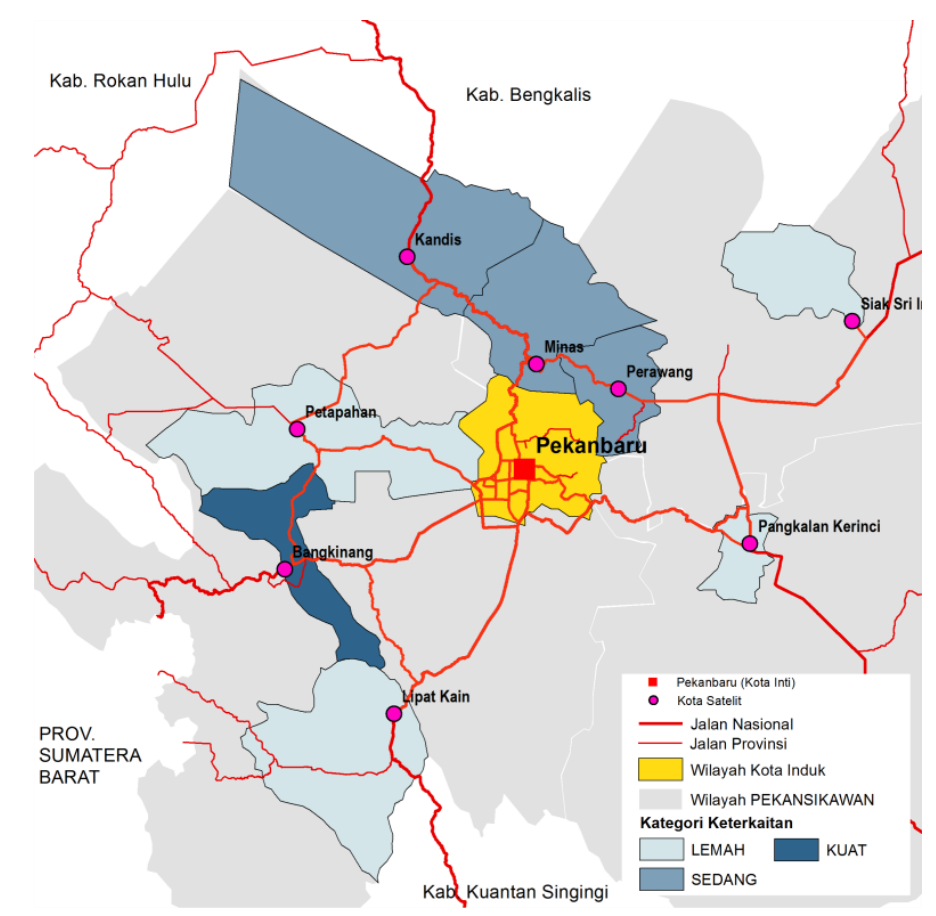

Gambar 8. Klasifikasi hasil skoring frekuensi keberangkatan di PEKANSIKAWAN

\subsection{Analisis keterkaitan fisik}

Dari analisis skoring yang dilakukan pada ketujuh indikator keterkaitan fisik yang diamati, dilakukan perkalian terhadap bobot masing-masing indikator yang dapat dilihat pada tabel 10. 
Tabel 10. Akumulasi skoring indikator keterkaitan fisik.

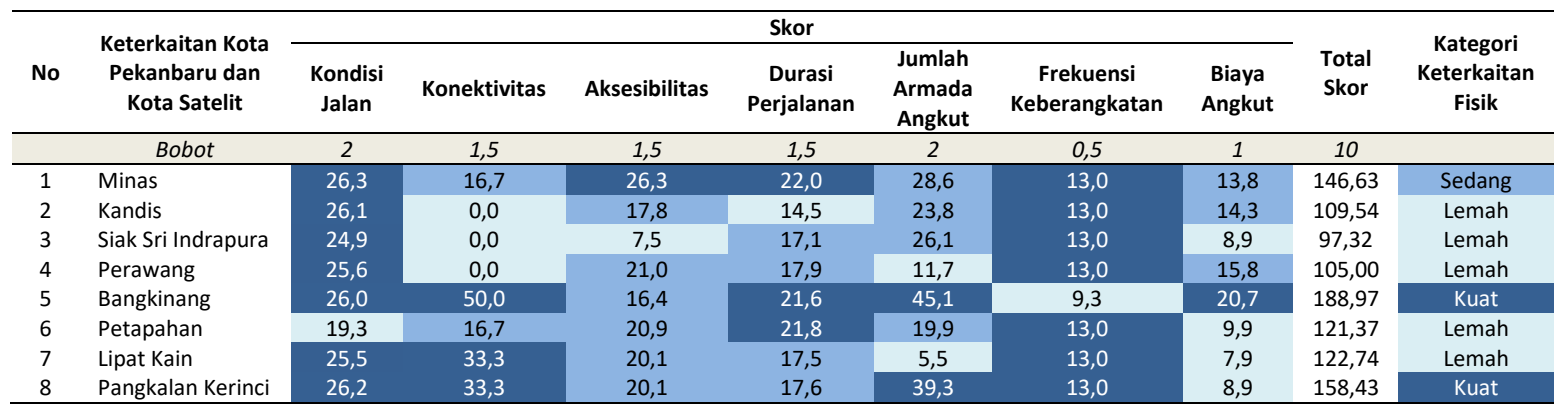

Dari hasil analisa pada tabel 10 dapat diketahui bahwa keterkaitan fisik antara Pekanbaru dengan Bangkinang, dan Pekanbaru dengan Pangkalan Kerinci dapat digolongkan sebagai keterkaitan fisik relatif kuat diantara kota-kota satelit lainnya. Keterkaitan fisik antara kota satelit Bangkinang dan kota inti Pekanbaru dipengaruhi oleh indikator kondisi jalan yang baik antara kedua wilayah tersebut, konektivitas yang baik dengan 3 jalur penghubung, durasi perjalanan yang singkat, jumlah armada angkut yang besar dan biaya angkut yang relatif murah dibandingkan kota satelit lain. Demikian juga dengan kota satelit Pangkalan Kerinci, keterkaitan fisik dengan kota inti Pekanbaru dipengaruhi oleh indikator kondisi jalan yang baik, konektivitas yang baik dengan 2 jalur penghubung, jumlah armada angkut yang besar dan frekuensi keberangkatan yang banyak dibandingkan dengan kota-kota satelit lain di kawasan metropolitan PEKANSIKAWAN.

Namun demikian, meskipun kota satelit Minas memiliki jarak yang paling dekat dengan kota inti Pekanbaru, keterkaitan Minas dan Pekanbaru tergolong sedang. Hal tersebut dikarenakan adanya beberapa indikator yang tidak terlalu berkontribusi terhadap besar/kuatnya keterkaitan kota satelit Minas dan kota inti Pekanbaru seperti indikator konektivitas dan jumlah armada angkut. Konektivitas antara Minas dan Pekanbaru hanya terkoneksi pada 1 jalur penghubung, dan angkutan penghubung kedua wilayah tersebut hanya berupa AKDP.

Secara spasial (gambar 9), eterkaitan fisik antara Pekanbaru dan kota satelit Bangkinang, Pangkalan Kerinci dan Minas dinilai sedang hingga kuat karena ketiga kota satelit tersebut merupakan daerah yang dilalui untuk menghubungkan Provinsi Riau dengan provinsi yang bertetanggaan seperti Provinsi Jambi, Provinsi Sumatera Utara dan Provinsi Sumatera Barat (sebagai pintu masuk Kota Pekanbaru). Jaringan fisik yang menghubungkan Kota Pekanbaru dan Sumatera Utara melewati Minas dan Kandis, sedangkan jaringan fisik yang menghubungkan Kota Pekanbaru dan Provinsi Jambi melewati Pengkalan Kerinci bahkan Pangkalan Kerinci - Pekanbaru - Minas - Kandis merupakan daerah yang dihubungkan oleh jalan lintas timur yang menghubungkan provinsi-provinsi di Pulau Sumatera (terhubung dengan jalur trans Sumatera). 


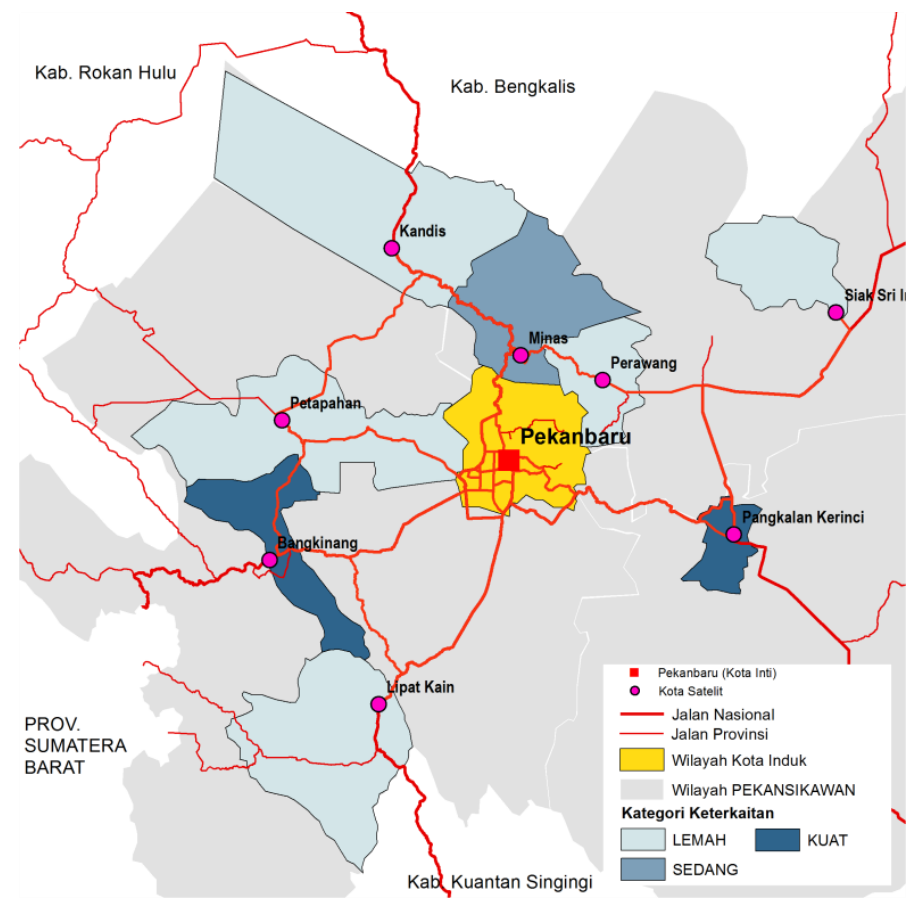

Gambar 9. Klasifikasi besar keterkaitan fisik kota inti dan kota satelit PEKANSIKAWAN

Jaringan fisik utama yang menghubungkan Kota Pekanbaru dan Provinsi Sumatera Barat melewati Bangkinang, yang terhubung langsung ke Kota Bukittinggi. Selain itu, jaringan fisik Bangkinang - Pekanbaru juga masuk kedalam jalur penghubung antara Pantai Timur dan Pantai Barat pulau Sumatera. Oleh karena itu, besarnya keterkaitan fisik antara kota inti dan kota satelit di kawasan metropolitan pekansikawan lebih dipengaruhi oleh keterhubungan jaringan jalan antara kota inti dan kota satelit di PEKANSIKAWAN dengan jaringan jalan yang menghubungkan Provinsi Riau (khususnya Kota Pekanbaru sebagai ibukota provinsi) dengan provinsi-provinsi disekelilingnya.

Keterkaitan fisik antara kota satelit Bangkinang, Pangkalan Kerinci dan Minas yang cenderung lebih kuat dibandingkan kota satelit lain dengan Kota inti Pekanbaru juga dapat dimaknai sebagai adanya hubungan interaksi antar wilayah yang kuat. Kuatnya interaksi antar wilayah yang kuat tersebut mempengaruhi kualitas dan kuantitas suplly and demand kedua wilayah tersebut (dalam segi perdagangan/ekonomi). Selain itu, dari sudut pandang hubungan antar wilayah, Pekanbaru, Bangkinang, Pangkalan Kerinci dan Minas sudah terintegrasi dengan baik sehingga ke empat kota tersebut memiliki arus perpindahan manusia, materi, informasi dan energi yang dapat dikatakan besar di kawasan metropolitan PEKANSIKAWAN.

Jika dikaitkan dengan faktor penyebab besarnya keterkaitan fisik yang telah dijelaskan sebelumnya bahwa kuatnya keterkaitan fisik dipengaruhi jalur penghubung utama antar wilayah di Pulau Sumatera, dapat juga dilihat sebagai salah satu faktor yang mempengaruhi integrasi kota inti dan kota satelit sehingga pergerakan manusia, materi, informasi dan energi menjadi lebih lancar. Dengan kata lain, terhubungnya kota satelit dengan jalur 
penghubung antar wilayah yang lebih besar akan meningkatkan hubugan interaksi dan integrasi kota satelit terhadap kota inti yang menjadi pusat pertumbuhan kawasan metropolitan PEKANSIKAWAN.

\section{KESIMPULAN}

Keterkaitan fisik kota satelit Bangkinang dan Pangkalan Kerinci cenderung kuat terhadap Kota Pekanbaru (kota inti) dibandingkan kota satelit lain di PEKANSIKAWAN. Sedangkan keterkaitan fisik kota satelit Minas terhadap Kota inti Pekanbaru cenderung lemah. Namun, ketiga kota satelit tersebut dapat dinilai memiliki keterkaitan fisik yang baik dengan Kota Inti Pekanbaru. Keterkaitan fisik antara kota satelit Bangkinang, Pangkalan Kerinci dan Minas terhadap Kota inti Pekanbaru lebih dipengaruhi oleh terhubungnya ketiga kota satelit tersebut dengan jalur penghubung utama antar provinsi di Sumatera, khususnya menghubungkan Kota Pekanbaru dengan Provinsi Sumatera Barat, Sumatera Utara dan wilayah selatan Sumatera. Keterkaitan Fisik kota satelit Kandis, Perawang, Siak Sri Indrapura, Petapahan dan Lipat Kain cenderung lemah terhadap Kota inti Pekanbaru. Lemahnya keterkaitan fisik keempat kota satelit tersebut lebih dipengaruhi oleh letak yang cenderung lebih jauh dari Kota inti Pekanbaru. Kota satelit Bangkinang, Pangkalan Kerinci, dan Minas yang cenderung baik diantara kota satelit lain di PEKANSIKAWAN akan berdampak kepada kuatnya keterhubungan dan integrasi antara Kota Pekanbaru dan ketiga kota satelit tersebut.

\section{REFERENSI}

[1] Katherina L K 2016 Kebutuhan Kerjasama Antar Daerah dalam Pembangunan Wilayah Diakses dari http://kependudukan.lipi.go.id/id/kajian-kependudukan/desakota/322-kebutuhan-kerjasama-antar-daerah-dalam-pembangunan-wilayah pada 11-06-2017

[2] Yudohusodo S 1988 Pembangunan Kota Baru dan Kota Satelit Seminar Nasional Kota Baru dan Kota Satelit Semarang, 29 Oktober 1988

[3] Kasikoen K M 2011 Keterkaitan Antar Wilayah (Studi Kasus: Kabupaten Cilacap) Jurnal $\begin{array}{llllll}\text { Planesa } & 2 & \text { pp } & 146-53 & \text { Diakses dari }\end{array}$ https://ejurnal.esaunggul.ac.id/index.php/planesa/article/view/548 pada 28-122019

[4] Daljoeni N 1992 Geografi Baru: Organisasi Keruangan dan Teori dan Praktek (Bandung: Alumni)

[5] Adisasmita R 2015 Analisis Kebutuhan Transportasi (Yogyakarta: Graha Ilmu)

[6] Rondinelli 1985 Applied Methods of Regional Analysis (United State of America: Praeger Publisher)

[7] Bendavid-Val A 1991 Regional and Local Economic Analysis for Practitioners: Fourth edition (London: Praeger)

[8] Sholahuddin M 2015 Sig Untuk Memetakan Daerah Banjir Dengan Metode Skoring Dan Pembobotan (Studi Kasus Kabupaten Jepara) Diakses dari http://eprints.dinus. ac.id/14957/ pada 10-10-2018 
[9] Sihotang D S 2016 Skoring dan Metode Fuzzy dalam Penentuan Zona Resiko Malaria di Pulau Flores JNTETI 5 pp 302-8 Diakses dari http://ejnteti.jteti.ugm.ac.id/index.php/JNTETI/article/view/278 pada 10-10-2018

[10] Sihotang D S 2012 Sistem Pemilihan Rute Perjalan Berbasis SIG Dengan Menggunakan Metode Skoring dan Metode Fuzzy Tesis (Yogyakarta: Universitas Gadjah Mada)

[11] Munawar A 2005 Dasar-Dasar Teknik Transportasi (Yogyakarta: Beta Offset)

[12] Rodrigue J P, Comtois C, dan Slack B 2006 The Geography of Transport System (New York: Routledge)

[13] Bhat C, et al 2002 Development of an Urban Accessibility Index: Formulations, Aggregation, and Application Center for Transportation Research The University of Texas Diakses dari https://ctr.utexas.edu/wp-content/uploads/pubs/4938 4.pdf pada 10-10-2018 